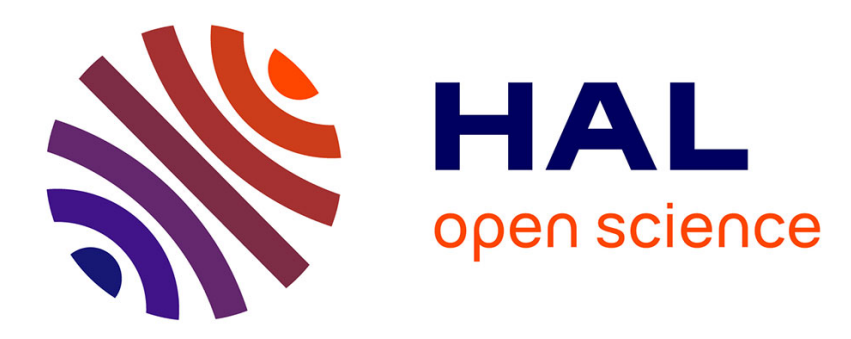

\title{
Spelling out Sensations: Reflections on the ways in which the Natural Environment can infiltrate Meaning-Making
}

\author{
Hélène Artaud
}

\section{- To cite this version:}

Hélène Artaud. Spelling out Sensations: Reflections on the ways in which the Natural Environment can infiltrate Meaning-Making. Senses and Society, 2016, 11 (3), pp.262 - 274. 10.1080/17458927.2016.1195109 . hal-01779393

\section{HAL Id: hal-01779393 \\ https://hal.science/hal-01779393}

Submitted on 11 May 2018

HAL is a multi-disciplinary open access archive for the deposit and dissemination of scientific research documents, whether they are published or not. The documents may come from teaching and research institutions in France or abroad, or from public or private research centers.
L'archive ouverte pluridisciplinaire HAL, est destinée au dépôt et à la diffusion de documents scientifiques de niveau recherche, publiés ou non, émanant des établissements d'enseignement et de recherche français ou étrangers, des laboratoires publics ou privés. 


\section{Spelling out Sensations: Reflections on the ways in which the Natural Environment can infiltrate Meaning-Making}

\section{Hélène Artaud}

To cite this article: Hélène Artaud (2016) Spelling out Sensations: Reflections on the ways in which the Natural Environment can infiltrate Meaning-Making, The Senses and Society, 11:3, 262-274, DOI: 10.1080/17458927.2016.1195109

To link to this article: http://dx.doi.org/10.1080/17458927.2016.1195109

Published online: 13 Oct 2016.

Submit your article to this journal \lceil

Џll Article views: 15

View related articles $\sqsubset$

View Crossmark data $ऍ$ 


\section{Spelling out}

Hélène Artaud is a Lecturer in Maritime Anthropology in the Hommes, Natures, Sociétés Department at the Muséum National d'Histoire Naturelle de Paris (MNHN). artaud@mnhn.fr

\section{Hélène Artaud}

ABSTRACT While French anthropology has spent considerable time examining the relationship between the body and society, it has not paid equivalent attention to the ways in which sensory skills are affected by the natural environment in which they have evolved. Mimetic processes inspired by "nature", such as onomatopeia and, as will be argued here, toponyms, are a valuable example of this phenomenon. Not only do they draw attention to the significant role that the natural environment plays in social meaning, but they also offer privileged insight into the ways in which perception of the environment is shaped and stabilized. 
KEYWORDS: senses, onomatopoeia, anthropology of the sea, toponymy, Imraguen (Mauritania)

\section{Introduction}

When M. Mauss published his text on the "techniques of - the body" in 1934, he emphasized the "imitative" aspects of learning bodily skills. However, Mauss focused primarily on a mimetic spectrum limited to people in whom the child trusts and who act as authorities, ignoring other behaviors that seemed to originate less from an imitation of social behavior than from close attention paid to the natural environment. ${ }^{1}$

Imitations of nature, whether made concrete in artifacts or expressed through language, seem to be found throughout the cultural field and shape both meanings and feeling. Examples of "natural" infiltrations into the social space are numerous. Consider, for example, different types of "lures" used in hunting, or linguistic practices such as onomatopoeia, both of which seem so spontaneously linked to the environment by "imitating" it's sounds (Dumarsais 1816). At the same time, these imitations of nature often prove to be partial or inexact, as if it were less important for these processes to reproduce "nature" than to communicate a unique, shared impression. What can these imitative procedures teach us about perception of the environment? What place do linguistic supports have in the education and expression of sensibility? What methodological value could an ethnographic investigation yield? These are some of the questions to be examined in this paper.

\section{Mimesis and Environments: from one Imitative Process to Another}

The role that the natural environment plays in the sensory education of a society has inspired very little anthropological reflection in France. Sparse allusions are scattered throughout ethnographic monographs, yet never give way to any true analytic approach. This is strange, though easily explained by the desire of some authors - following in Mauss' pioneering footsteps - to integrate the body into the social field, liberating it from the biological sphere where it has long been confined. In numerous human societies, the natural environment appears to be so closely tied to the minutiae of daily life that it seems difficult to ignore its contributions to sensory learning.

I have previously (Artaud 2013) sought to understand the role the environment plays in sensory learning by investigating a process that takes the natural surroundings as an important source of inspiration: the technique of "lures" or decoys. The lure, whose uses and purposes (hunting, pastoralism, ritual) are many in human society, is an especially meaningful example of the ways in which the senses "mimic" their natural environment. With this process, one 
might assume that the best results are guaranteed by accurate imitation of the natural world - whether auditory, as with animal calls and imitations, ${ }^{2}$ or visual or olfactory, as with lactation and adoption techniques. By duping a camel into producing milk with a mannequin "covered in the skin of its dead calf" (Bernus 2002) or tricking a game bird into complacency by mimicking its cries, lures seem to reward pastoralists and hunters for their exact imitations and near substitutions of nature. However, careful analysis leads to another conclusion. In most cases where lures are used, the "imitation" seems relative - fantastic, stylized and generally far from being a replica. ${ }^{3}$ Instead of being credible imitations, lures instead function as creative, sensitive translations of an object in nature, replicated so imperfectly that it cannot be fully integrated. Could this be true for other techniques where "imitation" of nature seems both so meaningful and spontaneous?

Imitative processes that draw inspiration from the natural environment, in particular, those aided by or named through language, can provide insight into these questions. While there are countless ways that the environment can infiltrate language, ${ }^{4}$ onomatopoeia is without a doubt the most emblematic example of linguistic "imitation" and the only one that has been the object of considerable study and ethnographic observation (Berlin and O'Neill 1981; Nuckolls 1996). Onomatopoeias, like lures, provide fertile ground for investigating the relationship between societies and their environment. The strong correlation between these processes quite often leads to some reduplication, as is the case with certain fishing techniques employed in the Palau archipelago:

Sounds made by various reef fishes are sometimes employed by underwater spearfisherman to locate or attract prey. Several species of angelfish bear the onomatopoeic Palauan name, ngemngumk. When said quickly with an emphasis on the vowels, the word reproduces the percussive grunting sound these fish make when alarmed. (Johannes 1981, 19)

Onomatopoeias here have a twofold value and efficiency: cynegetic, functioning like a trap to attract and locate prey, on the one hand, and linguistic, acting as a naming tactic in which sounds become a site of meaning, on the other. This latter characteristic of the onomatopoeia as a linguistic process that produces "acoustic material" calls for reflection.

Dumarsais offers the following definition for onomatopoeia: that of a figure, through which a word imitates the natural sound that it refers to (Dumarsais 1816). Despite its apparent simplicity, this definition is somewhat problematic. If the onomatopoeia is not an ordinary linguistic sign, in which the acoustic image and concept are joined together in an arbitrary fashion but is, instead, an acoustic image tied to a concept through adjacent sounds, it does not seem, 
for all that, to be a form of "imitation." The onomatopoeia, like the lure, must be more than a simple replication of the acoustic features of the world around it, otherwise, the onomatopoeic corpus would be a shared foundation for all human societies. ${ }^{5}$ A few examples gleaned from dictionaries would attest to the opposite, revealing an extraordinary heterogeneity. The rooster's cry is a famous illustration. Its transcription "cocorico" is familiar only to speakers of French. Anglophones expect "cock-a-doodle-do," while the sound is transcribed as "gaggalagaggalago" in Icelandic and "U-urru-U" in Turkish. If onomatopoeias are nothing more than simple imitations, and everyone hears the same sounds that inspire them, why then do they vary so significantly?

On this point, ethnographic literature provides several potential answers. The first that may explain these differences pertains to the environment in which a human group evolves. Each society creates its own onomatopoeias from the diverse referents and acoustic analogies directly inspired by their immediate environment. The Inuit, for example, base much of their onomatopoeic register on snow and ice: qiqiqrap refers to the crunch of snow underfoot, kalilqraq refers to the crunch that a sled makes on snow hardened by the cold, and usijupaaluuvaluktuq refers to the noise made by snow in contact with a sled that is bearing an especially heavy load (Therrien 1990, 38).

However, the ecological specificity of the Inuit environment cannot alone account for the range of onomatopoeic refinements that certain elements of their reality give rise to. Indeed, one of anthropology's non-negligible contributions has been to show that, in similar natural environments, different societies will focus on different elements. The contingency of choices that a given culture makes about its natural environment was particularly emphasized by French anthropologist Claude Lévi-Strauss. In his work Le regard éloigné (The View from Afar), he notes that each society settles on a few distinctive features of its environment, but that no one can predict what they will be or what uses they will be put to $(1983,145)$. These salient perceived features can be explained by delving into the symbolic world of a given group: the mythological, epistemological and historical underpinnings that allow one to identify the perceived characteristics upon which a society lingers, and the ways that people are inspired to interpret their natural environment. While Lévi-Strauss endeavored to see the perceived environment not as a collection of unique representations, but as a shared view that would be therefore susceptible to interpretation, he makes no mention of sensory dispositions within this foundational work of cultural heuristics. However, sensory dispositions can also influence a society's access to elements of its environment and draw attention to a particular dimension of its nature. Anthropological works on the senses tend to illustrate this fact, identifying the privileged sensory "wiring" through which particular societies most intimately connect with their environments. ${ }^{6}$ 
Like mythology, epistemology and collective history, these sensory tonalities, apparently distinct from one society to the next, seem to offer heuristic keys for understanding how environmental perception is structured on a partial and partisan basis. Accordingly, both the onomatopoeia and the lure seem to reveal something about the way in which the environment is perceived through the senses. Rather than perfectly "imitating" the environment, onomatopoeias and lures seem to draw on certain features that are then simplified in a preferred sensory form: acoustic for onomatopoeias, and visual, auditory, olfactory, tactile or gustatory - or some combination thereof - for lures.

Mimetic processes inspired by the natural environment - whether they be objects (traps, bird calls, and masks) or interiorized (animal call techniques, onomatopoeias) - have an undeniable place. Their analysis seems to show that a social group's perception of the environment is partial and incomplete, revealing specific irregularities and salient features that can only be accounted for through an exploration of representations and sensibilities. However, it remains unclear what role linguistic processes of this nature play in the education and expression of the sensory experience. While I do not intend to revive one of the most fertile debates in philosophy - whether thought or language comes first ${ }^{7}$ - the reflections below do fall within its horizon. Mimetic and linguistic processes inspired by nature call for an investigation into the processes through which humans perceive the environment. The marine toponymy of the Imraguen fishermen of Mauritania may provide some insight into the role that language plays in sensory understanding.

\section{The Marine Toponymy of Imraguen Fishermen: some Insight into the Senses}

The Imraguen people of Mauritania have long constituted the only fishing community within the nation's chiefly pastoral Moorish society Their fishing practices, conducted with little equipment and, up until the early twentieth century, without boats, have given them little specific control over their maritime space. ${ }^{8}$ However, this scarcity of materials seems to have broadened their modes of interaction with the milieu, prompting a wider variety of innovations and compensations in terms of the senses and body techniques. Hearing plays a fundamental role in their understanding of the maritime environment, and acoustic reference points form a valuable support for navigating different zones. These are particularly numerous due to two notable features of the ecosystem. On the one hand, the density of islands and tidal flats, which shelter local fauna, increase the number of acoustic focal points. On the other, the extreme variation of depths in this area create audible contrasts between shallow and non-shallow areas, or during the passage from one to the other. This maritime environment is therefore a space filled with auditory 
obstacles, and recognizing them is essential to fishing and navigating. These acoustic indicators (birdsong, jackal calls, hissing snakes and audible contrasts in water depth) act as beacons that are so constant -acute hearing being such a meaningful point of access to this maritime world - that they have become integrated into the toponomy itself as common reference points.

Many of the numerous toponyms present in the Banc d'Arguin marine area, home to several Imraguen communities, are formed of purely acoustic elements: "Eketkat Teyshot," "Awker Tentaz" and "Ayun eșșerșar" are emblematic examples. Through the structure and composition of their names, each of these toponyms describes the physical characteristics of the environment or an event that occurs there. The zone named "Eketkat Teyshot" is difficult to navigate due to its shallow depth. Here, "Teyshot" is the name of the village facing the maritime zone. "Eketkat" means nothing specific in the vernacular, but according to fishermen, it echoes the sound produced by the water hitting the flank of a lanche (the small fishing boats used in this area). The place named "Awkər Tentaz," which directly refers to a zone where water trapped in a shallow cavity quivers when the sun reaches its peak, follows a similar convention. "Awkər" is the word for a place where there is no plant cover, whether on land or at sea. "Tentaz" is the onomatopoeia that mimics the sound water makes when it is about to boil. According to fishermen, the heat in this area is so intense that the water sizzles and makes this distinctive sound. Finally, "AAyun eșșerșar" is formed of the words "'Ayun" (singular "Ayn"), "canal", and "essersar," which is the onomatopoeic word for the sound that lauches make when passing through. The seabed here is littered with countless shells and pebbles, and a very specific sound is made when a lanche moves through at low tide, pushing them aside.

First, it should be noted that, as previously discussed, "imitation" does not seem to be predictable, for the most part because it seems to break down the natural environment into elements that are so particular they cannot be anticipated. We will return to this point later. These examples also lead us to a second conclusion about the context in which these onomatopoeias appear: toponymy. The purpose of toponyms is to establish a connection between places and their physical, remembered and biographical features, that is to say, the relationship between a sensory or emotional feature and an identified space. The analysis of toponyms therefore allows a more subtle onomatopoeic register to emerge, distinct from that usually heard in everyday life. By giving voice to specific perceptions, otherwise undetectable, toponyms build a shared view of the environment. They therefore contribute to a more comprehensive understanding of the ways perception of the environment is structured, beyond the mimetic procedures under analysis here. Toponyms can teach us the importance of sensory experience in knowing the sea, and this experience encompasses more than just auditory features. Visual, 
olfactory and tactile indications also become a part of the "landscape" and act as referents when composing the name for a given zone.

The visual indicators that are included in a zone's toponymy are varied in nature. The most frequently used ones are based on the appreciation of chromatic differences in the water. These changes in hue depend on the density of algae present, variations in depth, and the elements covering the seabed: sand and stone. Zones tend to generally alternate between those called "labyāl," "white," or "kahlä," "black." The darker hues are associated with denser plant cover and deeper waters, as with the zone named "Krā̄ kahle," while lighter-colored zones such as "krā̄ labyāl" are strewn with pale stones or seashells. ${ }^{10}$ Beyond changes in color, marine spaces are also named after the reflective capacity of their waters, specifically places where the glittering is more intense. The zone named "Awkər Tišimdəyin" is a good example. As previously stated, "Awkər" describes a place similar to a desert, and in znāga (the Berberophone dialect originally spoken in the region), "Tišimdəyin" means "collection of mirrors." Here, the term is intended to describe the unique sparkling of the water in this area of the Banc.

Olfactory and tactile registers are also widely used. The smells of the tidal flats - particularly noticeable in certain areas due to the presence of certain plants - are often a dominant olfactory theme, as with the zone called "Inevaven." During low tide, a specific type of mud becomes a notable olfactory feature in this isolated zone: the word "Inevaven" refers to a long-lasting, unpleasant smell, here caused by "tavadit" (eelgrass). The most frequently used tactile indicators refer to uneven underwater terrain, which the fishermen know in intimate detail. They use their poles ("mūqzəvv"11) to determine the depth of the seabed and what it is made of: mud, stone or shells. The zone named "șag'a ə/-hargve" falls into this category. "Sag'a" refers to a small island that is most visible at low tide. "Hargve" means "hip." This name tells fishermen that they can step into the water (which will be only hip-deep) and apply the appropriate fishing techniques. It also warns those passing through that they must be vigilant when steering their lanches through the shallow waters.

The pervasiveness of sensory elements in maritime place names reveals the close relationship, cohesion even, between language and the senses for the Imraguen people. The language reveals a complex sensory landscape, which combines elements from the natural world drawn from an extensive sensory register. There is no privileged sensory wiring: Imraguen communities are not strictly hearing-based, but instead come from a world full of perceived sensations that are often included in their toponymy. All the same, perception of the environment in mimetic processes like onomatopoeia is still based on partiality: not everything that is seen, felt or smelled is regarded equally, and, though some senses may be privileged in 
the toponymy of a given place, perception still appears to be structured on the basis of fragments, subtle characteristics.

It also seems pertinent to point out the effect that linguistic registers have on the speakers themselves. Expressed in language, the most unique and understated sensory features (as with the zone named "Awkər Tišimdəyin," whose glittering surface is believed to be more remarkable than others) become a shared point of appreciation and create a lasting representation of the environment. Singular perceptions of the sea are therefore crystallized in language through toponyms. They ensure that impressions are transmitted and occasionally remind those passing through to pay attention to specific objects - often intangible - and sensory ties - often weak - that language has preserved in memory. This use of language to stabilize sensory experiences calls for a deeper analysis of the value and impact of such devices.

\section{Language as Shared Perception}

Audible cues are not the only sensory material that language draws upon to identify a locale. Imraguen fishermen develop their perception of the maritime world through a polysensory experience that is open and subject to constant change. This sensory foundation comes with a host of difficulties for both researchers and the society itself.

When a society's relationship with the world is built on its own sensibility, research that attempts to understand the nature of this connection comes up against new problems. Conceptualizing this close link to the sea, understanding a world in which perception is so closely tied to sensibility, requires an approach that still defies epistemological classification, an approach in which the anthropologist's own body is not implicated. Stoller invited anthropologists to "open their senses to the worlds of their others" (Stoller 1989, 7). But is this really possible? Can anthropologists truly use their senses to comprehend a multitude of worlds and sensory experiences? I have discussed elsewhere (2011) that, in spite of my efforts to perceive the sensory features that the fishermen were pointing out - features which are tangible to them, such as the rumble of the corvina (Argyrosomus regius) and the rattle of foam against the sides of a lance - they were to me nothing more than a jumble of light and noise. Training one's body to be receptive to the messages of the sea would take a lifetime and would, more importantly, lead to this paradox: once they have been fully incorporated, it would become impossible to describe them. Once a body has been domesticated by the sea, trained in the harshness of its waves and the subtleties of its logic, it loses the ability to articulate the steps through which they have been incorporated. It can no longer spell out the signs. How then, can one transmit and express ways of living in the world that defy all attempts at conceptualization, not from lack of trying 
but because this knowledge is gained through such close ties to the body that any distance results in its loss?

Marcel Mauss, whose "techniques of the body" were mentioned in the introduction, had intuited this subtle yet drastic opposition. By emphasizing the importance of these body techniques, as well as their range and disparity from one society to the next, the author brings this as-yet unexamined ${ }^{12}$ fundamental methodological difficulty to the reader's attention. It is true that anthropological study is greatly hindered by the fact that our sensibilities are tightly bound to our unique cultural upbringings and in many ways shaped by the teaching we have received. There are two main reasons for this. The first, already mentioned, stems from the anthropologist's inability - as she is also the custodian of unique attention and bodily abilities - to reform or alter her access to a reality that she has been conditioned to accept. As Mauss remarked, "I cannot get rid of my technique" $(1973,71)$. The second reason stems from the paucity of categories available through which the anthropologist can understand sensibility. Linguistic processes such as onomatopoeia are therefore of methodological interest to anthropologists in offering an - otherwise inaccessible - avenue for comprehending various sensory representations of the world. As Michèle Therrien observes:

onomatopoeias, verbal phrases and specific affixes are excellent indicators of the richness of auditory (and more broadly, sensorial) experience. [...] They provide precious information on the un-articulated message, which is, indeed, a message, a form of communication in the sense of words exchanged between speakers. $(1990,38)$

The idea that language can be a fruitful medium for understanding a society's perceptions is not new. This insight can be largely attributed to ethnoscience, in particular, and, was recently recalled in an issue of this very journal (Majid and Levinson 2011). Less clearly defined was the impact that such processes can have on a speaker's sensibilities. As already mentioned above, the power of language, both in processes like onomatopoeia and in elements involving naming such as toponymy, is its ability to transform sensations into a register of enduring terms and stabilized content that can be transmitted and become shared referents.

The difficulty the anthropologist faces in attempting to apprehend the world on the basis of its diverse and ever-changing sensory foundations is equally present, and particularly acute, within the collectivity itself. As demonstrated elsewhere (Artaud 2012), sensory experiences are not necessarily homogenous within a given social group, and techniques of the body alone cannot explain an individual's sensory disposition. The latter depends on the individual's unique and complex sensorial, memorial, and biographical background to which society provides the particular contours. The social 
milieu creates, in effect, a sheath through which sensory materials are re-examined and given form. It cannot supply individuals with sensory material, except through certain processes where sensory content is made obvious through a linguistic form, as with onomatopoeia (sensory linkage) and toponymy (unique perceptive content transmitted through the name). Language in this case acts, in part, as a vector for standardizing sensory experience.

Once again, the Imraguen fishermen provide invaluable material for this avenue of thought. Beyond the common template of the fishermen's' training, and the attention they consequently pay to the same natural features, individual variables also emerge, arising, it seems from the idiosyncratic physical dispositions of the individual trainees. Thus, in spite of sharing similar knowledge and awareness of environmental indicators and retaining the same details of their itineraries, two different fisherman will base their perception on diverse sensory experiences. When passing through a specific zone, ${ }^{13}$ the same signs are indicated: the water becomes lighter and shallower, which should incite the navigator to be especially vigilant. However, this same fact is perceived differently by the senses: one may sense this by probing with his pole, while the other notices the change in seabed color. The same meaningful elements are evoked but with sensory variations in how they are apprehended and anticipated. It is through language - the types of linguistic processes discussed here - that these different sensory perceptions of the environment, for which I have set out a "genealogy" elsewhere (Artaud 2011), can be unified, reducing, in a way, their range and variety. By expressing, through the same linguistic entity, contrasting ways of understanding the environment, language provides a framework that can be used by individuals with different sensibilities and perceptive skills to help create a shared sense or perception. The Imraguen people show that these processes are doubly effective: not only do they offer anthropologists a window onto this dimension so fundamentally "other" that is the sensory foundation of human societies, they also act within the group as vectors of stabilization, standardization and transmission of marine sensory representations - sometimes the most discreet and particular.

By analyzing imitative processes inspired by nature, we can understand how perception of the environment is structured. It is derived from elements that are partial, stylized and changing. In examining the role that onomatopoeia plays in the toponymical system of the Imraguen people, we have seen that it is not the only means of conveying the subtle, fragmented elements individuals are confronted with in their perception of the environment. Toponymy as a whole demonstrates how the senses are bound to a sensory perception of nature that relies on a broader sensory spectrum. If processes such as these are so invaluable for understanding a given society's perception of the environment and the ways in which its features are stylized, it is because they stabilize our understanding of 
the environment and channel the evanescent dispersion of sensory perceptions that arise from it.

\section{Acknowledgments}

I wish to thank the UMR 7206 Eco-anthropology and Ethnobiology research unit in the "Hommes, Natures, Sociétés" department of the Muséum national d'histoire naturelle for supporting the translation of this article.

\section{Notes}

1. Social "imitation" refers all of the mimetic processes (reproduction of facial expressions, adopting the same postures, linguistic accommodation) inspired by another individual. Imitation in social contexts is often intended to regulate emotions: by normalizing the expressions of the body, imitation allows the listener to interpret a speaker's bodily cues, to take part in them. "Echoing the body movements of another allows the person doing the echoing to bring themselves into an emotional state similar to their partner's. The body serves as a tool for understanding the emotions of another" (Cosnier 1998, 183). The goal is entirely different for environmental imitation.

2. Birdcall techniques are especially common among the Siberian nomads. They consist of "emitting a vocal sound in order to influence an animal's behaviour". This sound is most frequently an "imitation" of an animal's cry.

3. Serge Bahuchet notes that in the case of the vocal performances of Pygmy hunters, the imitations of animal cries are often "inexact" (Bahuchet 1985, 283).

4. Without necessarily coming from the natural environment and imitation, strictly speaking, other linguistic entities such as, for example, ideophones, also question the ways that the sensed world (sensation, odor, color, form and sound) is mobilized in discourse, ways that are not completely arbitrary.

5. However, the debate is not yet resolved. Authors such as Berlin see in onomatopoeia a strong point in favor of the universalist theory.

6. The most notable example in this context comes from S. Feld (2012) with the Kaluli, but other texts, such as one from Vishvajit Pandya on the olfactory cosmology of the Ongee in the Andaman Islands, or S. Rasmussen (2006) on touch among the Tuareg people in Mali, follow a similar path.

7. The "opposing" sides of this debate are: those who do not see thought as preceding language, who believe that it is through our words that we think - that we only have awareness of our determined real thoughts when we give them objective form, which we differentiate from our interiority (Hegel, Encyclopédie 
III, Philosophie de l'esprit, §462): and thinkers who believe the contrary, that thought remains incommensurable with language (Bergson, Essai sur les données immédiates de la conscience).

8. The relationship between fishermen and the sea was deemed nonexistent and unworthy of attention solely because they lacked any tools adapted to the environment.

9. "Krā

10. The most often due to the presence of "Ag்uvâl" (Cymbium sea snails).

11. Poles made from the vərnān plant (Euphorbia balsamifera Aiton).

12. Remember, however, that a school of philosophers such as Condillac had already emphasized the benefits of learning from the senses. In his Traité des sensations (1754), Condillac already made a distinction between sight, a strictly organic, spontaneous process, and looking, which implies a reflexive process: he stated that "eyes do not need to learn to see, but rather they must learn to look" (III, 3, 171).

13. Here I am referring to Sirra, an area characterized by a complex maze of shoals.

\section{References}

Artaud, H. 2011. "La poïétique des flots: ouvrir, construire et refermer la mer dans le Banc d'Arguin, (Mauritanie) [The poetics of the waves: opening, constructing and enclosing the sea in the Banc d'Arguin (Mauritania)]." PhD thesis, École de Hautes Études en Sciences Sociales.

Artaud, H. 2012. "Sobre una antropologia sensible del mar [Toward a sensitive anthropology of the sea]." Quaderns-e de l'ICA 17 (1): 91-103.

Artaud, H. 2013. "Introduction." Cahiers d'Anthropologie Sociale 9: 9-15.

Bahuchet, S. 1985. Les Pygmées Aka et la forêt centrafricaine [The Aka Pygmies and the Central African forest]. Paris: SELAF.

Berlin, B., and J. P. O'Neill. 1981. "The Pervasiveness of Onomatopoeia in Aguaruna and Huambisa Names." Journal of Ethnobio/ogy 1 (2): 238-261.

Bernus, E. 2002. "Laits touaregs. Usages et symbols [Tuareg milks: uses and symbols]." In Ressources vivrières et choix alimentaires dans le bassin du Tchad [Food Resources and Dietary Choices in the Chad Basin], edited by C. Raimond and E. Garine, 399-412. Paris: IRD Éditions.

Cosnier, J. 1998. "Empathie et communication [Empathy and communication]." Éditions sciences humaines 68: 181-185.

Dumarsais, C. C. 1816. Des tropes ou des différents sens dans lesquels on peut prendre un même mot dans une même langue [Tropes or the different senses in which one can take the same word in the same language]. Paris: Impr. de Delalain. 
Feld, S. 2012. Sound and Sentiment: Birds, Weeping, Poetics and Song in Kaluli Expression. Durham: Duke University Press.

Johannes, R. E. 1981. Words of the Lagoon: Fishing and Marine Lore in the Palau District of Micronesia. Berkeley: University of California Press.

Lévi-Strauss, C. 1983. Le regard éloigné [The view from afar]. Paris: Plon.

Majid, A., and S. C. Levinson. 2011. "The Senses in Language and Culture." The Senses and Society 6 (1): 5-18.

Mauss, Marcel. 1973. "The Techniques of the Body." Economy and Society 2 (1): 70-88.

Nuckolls, J. 1996. Sounds Like Life. Sound-Symbolic Grammar, Performance and Cognition in Pastaza Quechua. Oxford Studies in Anthropological Linguistics. Oxford: Oxford University Press.

Rasmussen, S. 2006. Those Who Touch: Tuareg Medicine Women in Anthropological Perspective. Dekalb: Northern Illinois University Press.

Stoller, P. 1989. The Taste of Ethnographic Things: The Senses in Anthropology. Philadelphia: University of Pennsylvania Press.

Therrien, M. 1990. "Traces sur la neige, signes sur le papier. Significations de l'empreinte chez les Inuit Nunavimmiut (Artique québécois) [Traces on the snow, marks on paper. Meanings of print among the Nunavimmiut Inuit (Quebec Arctic)]." Journal de la Société des Américanistes 76 (1): 33-53. 